\title{
THERMOCHEMISTRY COMIC AS A SELF-LEARNING RESOURCE FOR GRADE 11 STUDENTS
}

\author{
Siska Oktapianti \\ Chemisry Education Department, Universitas Islam Negeri Antasari, \\ Banjarmasin, Indonesia \\ Email: siskaoktapianti21@gmail.com \\ Website: http://jurnal.uin-antasari.ac.id/index.php/itjik \\ Received: 10 August 2020; Accepted: 1 July 2021; Published: 2 July 2021
}

\begin{abstract}
The aims of this developmental research are: (1) to develop a chemistry-based comic book in thermochemistry chapter, (2) to evaluate quality of the chemistry comic book based on assessment of chemistry teachers and students at senior high school/Islamic senior high school. This research used procedural model of descriptive which contains various steps to follow in order to launch a product. The development of this chemistry comic book was guided by thesis supervisors, media experts and peer reviewers. In the regards of the comic book evaluation, this research adopted a set of evaluation instruments which incorporated by several aspects and criteria. The evaluation was presented in qualitative data, then the results was tabulated and analyzed by the guided evaluation criteria and category to measure the quality of the chemistry comic book. This comic covered 5 (five) sub-topics, e.g. heat, enthalpy and enthalpy change, calculating enthalpy changes, calorimeter, and fuel. According to the evaluation converted by 3 (three) chemistry teachers and 30 (thirty) students, the chemistry comic book developed in this research is well-qualified. According to the teachers' assessments, the chemistry comic book showed to have a good quality within the score of 146.33 from the maximum point of 190 and ideal percentage of $77.02 \%$. Likewise, based on the students' assessment within the score of 106.33 from the maximum point of 135 and ideal percentage of $78.76 \%$, revealed the same result. Lastly, by the results and several developments, the comic book is expected to use as the guideline of the additional study sources.
\end{abstract}

Key Words: chemistry comic book; thermochemistry; self-learning resource

\section{INTRODUCTION}

Many people consider that the existence of 2013 curriculum leads to be a big concern and cause controversy as they think that they are not ready to implement it (E.Mulyasa, 2013). In the regards of the implementation of 2013 curriculum, there are three related dimensions that cannot be separated, including planning, teaching \& learning process, and learning evaluation. The planning will establish the study materials will be taught in prior, the learning media will be choosen, and the methods will be used in teaching \& learning process.
In addition, selecting good and effective learning media without timeconstraint is essential in the implementation of 2013 curriculum since learning should not be only executed during school hours, but also it can be done at any time without time limitation. Thus, learning and teaching process should not be limited by space and time.

Furthermore, in chemistry learning, as it is stated by Sunyono (2005), that the student's poor learning outcomes are due to their low understanding and interests of chemical concepts and chemistry lessons respectively. Considering that, the teachers are unable to provide concrete and 
meaningful learning concepts and examples which actually are existed in the surroundings of learning environment and often encountered by students. Consequently, the teachers are required to create compelling and engaging classroom ambiances, so that the learning and teaching process could be performed optimally.

Hasruddin (2013) said that the reliable textbooks and the use of animation media can make students more committed to explore study materials, for as much as reading lots of textbooks that are systematically arranged, interesting, and right on target, they tend to be more engaged and developed. Furthermore, Depdiknas (2008) also pointed out that textbooks are useful for: (1) Assisting lecturers / teachers in the learning process; (2) Facilitating the presentation of class materials; (3) Guiding students to study in extra times; (4) Assisting students, as they do not depend on teachers alone as the only source of information; and (5) Fostering student motivation to develop themselves in digesting and understanding lessons.

However, currently, the learning media used by teachers is mostly lack of creativity and innovation, so students tend to be bored and less interested in the learning process. This was based on the author's observations of several schools, namely SMK (Vocational High School) Muhammadiyah 2, SMA (Senior High School) Internasional Budi Mulia Dua, and MA (Islamic Senior High School) Wahid Hasyim. To obtain the aforementioned result, the researcher conducted interviews with students of these schools which showed generally, the students were less motivated in the learning process since the learning activities and approaches carried out by the teachers was less attractive and conversely they only focused to assign students with assignments. In fact, the teachers also have not tried and used the comic book as the learning resource before. Based on the explanation above, the researcher is interested in conducting research by developing this matter under the title of "Thermochemistry Comic as a Self-Learning Resource for Grade 11 Students".

The purpose of this study is to develop a chemistry comic book as chemistry learning media and resource. In details, the researcher will make a comic by using Doraemon's and his friends' figures since the characters have been already well-known in Indonesia. The figures in this comic are Doraemon, Nobi Nobita, Shizuka Minamoto, Takeshi Goda (Giant) and Suneo Honekawa. Additionally, Doraemon was written by Fujiko F. Fujio who is very popular globally. According to the information retrieved from wolipop.detik.com on July 18, 2020, Doraemon is the best anime of all life-time and the storyline is also interesting and compelling to watch. Thus, almost walks of life have watched it, including students who are already more familiar with these figures.

According to Devi Afriyuni Yonanda et al (2019), comic could improve critical thinking ability of students. This was also in line with another research showing that cartoon could give positive effects towards student learning outcomes, as Green \& Myers (2014) reported that the use of cartoon in curriculum or instructional design increased student interest in learning. Next, Fitri Dwi Arini (2017) also highlighted that the use of comic as a learning resource could improve the learning interest of students.

As a matter of fact, comic book and characters are not something unfamiliar on the daily basis, especially for students who are accustomed to watch television and read comics. Afterwards, comic can be used as an alternative medium in the learning process because it is identical to something that does not create tension yet energized. It is one of the visual media that can be utilized in learning and teaching 
process as reading comic is an activity which is commonly encountered in the daily life and it has a high-comfort value, while chemistry acted as a subject which is encountered in school and regarded as something abstract and complicated. So that, the researcher is challenged to combine two contradictory things that can be used as something interesting, fun, and educational as a part in creating a fun chemistry learning.

\section{RESEARCH METHOD}

This research used a mixedmethods approach which obtained more comprehensive data by combining qualitative and quantitative approaches, (Sugiono, 2011). The researcher used RnD research method which aimed to produce/develop certain products, as well as to test the effectiveness of these products in a study. The research was carried out in stages so that the results of these products can be useful for users of the wider community, (Sugiyono, 2011).

According to Borg and Gall (1983), $\mathrm{RnD}$ is a process used to develop and validate educational products. This process consists of studying research findings

\section{RESULTS AND DISCUSSION \\ 1. Planning}

In this stage, the reasearcher designated a topic of thermochemistry in the comic book, based on the interviews with students of several selected schools, specifically SMK Muhammadiyah 2, SMA Internasional Budi Mulia Dua, and MA Wahid Hasyim. Then, the results obtained that generally students were less motivated in the learning process because the learning approach and media carried out by the teachers was less attractive and the students were only more assigned to do the assignments. In addition, the novel approach of learning media in the form of chemistry-based comic book have not been used yet in their classrooms. In details, these students said that they are fond of pertinent to the product to be developed, then developing the product based on the findings, field-testing the product in the setting where it wil be used eventually, and lastly revising it in order to improve the deficiencies found in the field-testing stage.

The developmental model used in this study is procedural model that is a descriptive model due to its simplicity and convenience, however this model contains various steps to follow in order to launch a product. There are 4 (four) stages covered in this procedural developmental model, which are: (1) planning, (2) organizing, (4) implementating and (4) asessing.

The subjects of this study are students and teachers of of several schools, namely SMK Muhammadiyah 2, SMA Internasional Budi Mulia Dua, and MA Wahid Hasyim. The data collection techniques and instruments used in this study were interview guides, questionnaires and observations. This study used data analysis in the form of descriptive verbal data which was analyzed qualitatively, meanwhile the quantitative analysis was used to analyze the assessment score.

reading comic and many of them possessed comics in their home. Hence, the researcher was interested in making comic as learning media, especially comic book of chemistry based on Curriculum 2013 criteria. Overall, this comic included 5 (five) sub topics, i.e. heat, enthalpy and enthalpy change, calculating enthalpy changes, calorimeter, and fuel.

\section{Organizing}

In organizing phase, the researcher collected references and drawn the comic's designs accordingly. Altogether, these references were taken from various sources such as books, journals and thesis. In drawing comic's design, the researcher used Corel and Adobe Photoshop CS3. 
Tarbiyah: Jurnal Ilmiah Kependidikan

Vol. 10 No. 1 January - June $2021(57-63)$

DOI: http://dx.doi.org/10.18592/tarbiyah.v10i1.3869

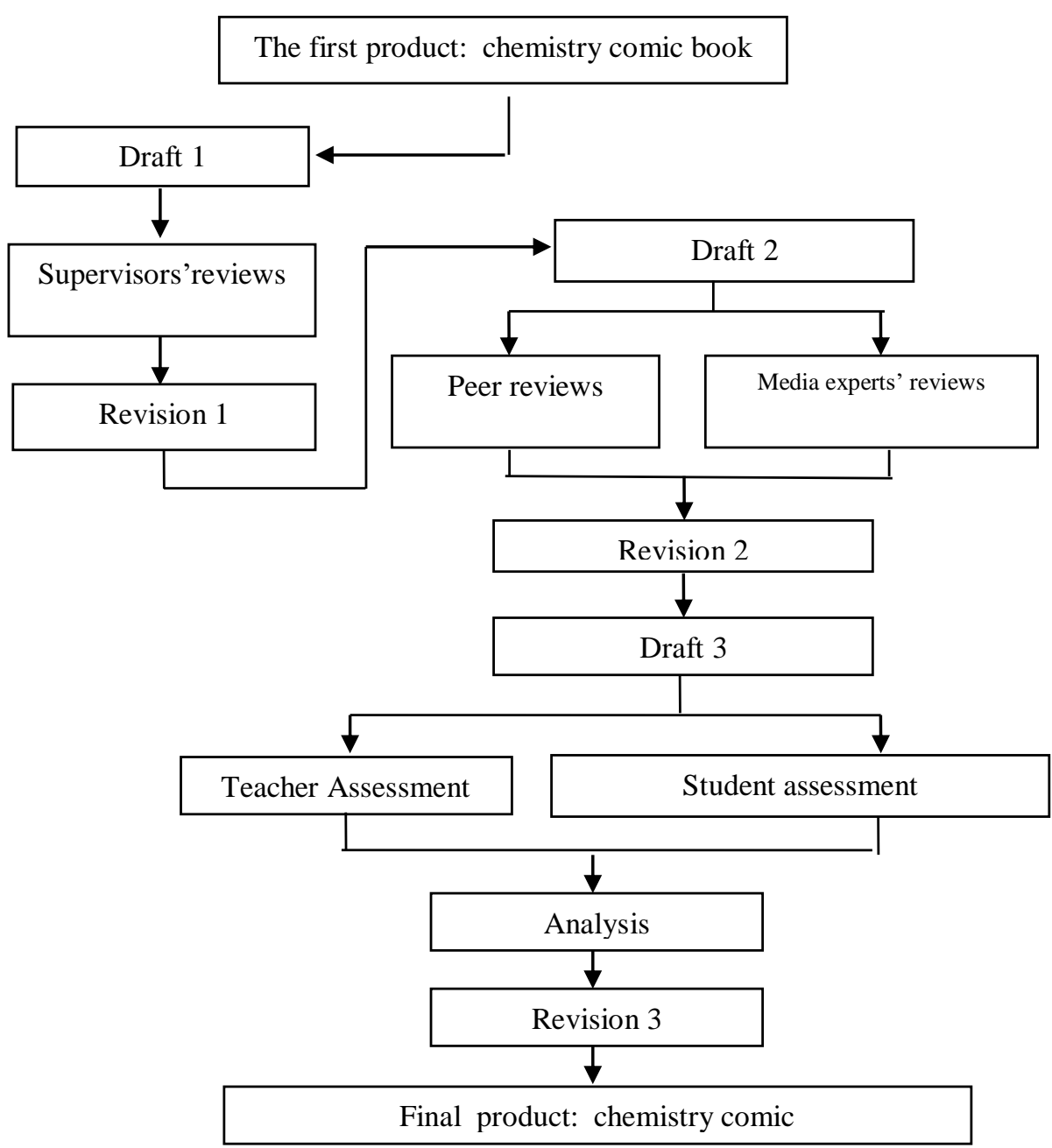

Picture 1. The Scheme of Comic Process

\section{Implementating}

In this stage, the researcher finally drawn and consulted a chemistry comic

book of Thermochemistry by using Corel and Adobe Photoshop CS3.

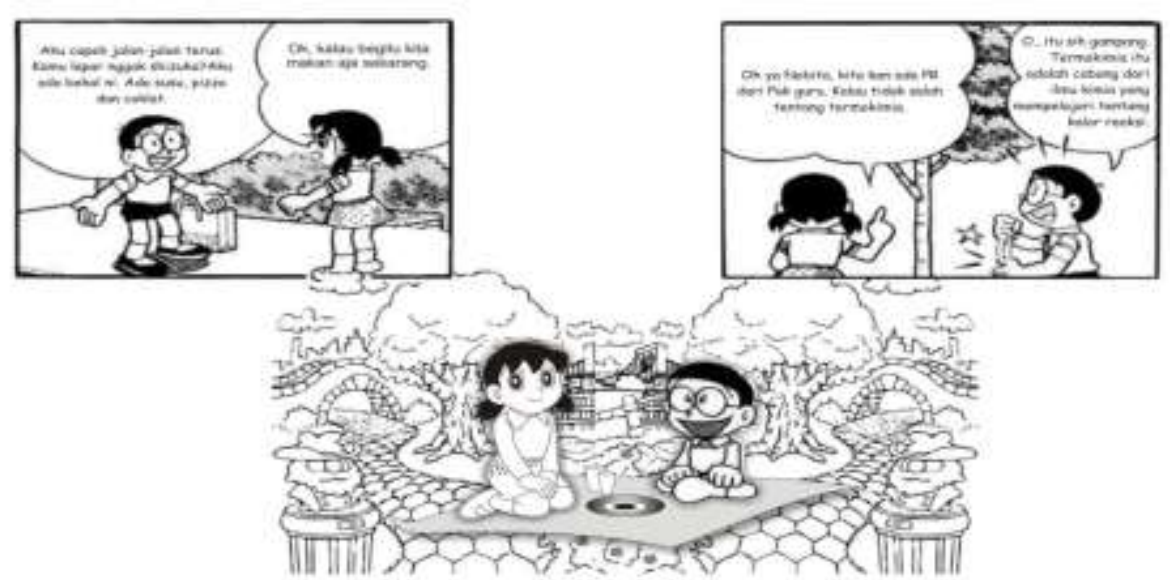

Picture 2. Sample of Comic by Using Corel and Adobe Photoshop CS3 
After making this comic, the researcher consulted the comic drafts to the supervisors, peer reviewers and media experts before producing the final one. There were three revisions made for the chemistry comic book product before it will be assessed by the teachers and the students. Furthermore, there are some inputs and evaluation adopted to support the quality improvement of the chemistry comic book prior to be assessed by.

Eventually, the chemistry comic book will be revised after getting several inputs and adjustments from the media experts. Again, the comic book was consulted to supervisors to obtain the second revision. Finally, the final product in the form of comic book was assessed by targeted chemistry teachers and students from the aforementioned-selected schools, namely SMK Muhammadiyah 2, SMA Internasional Budi Mulia Dua, and MA Wahid Hasyim

Some inputs taken for improvement are :
a. To add interesting images.
b. To shorten dialogues.
c. To put important pattern in box.
d. To make several evaluations.
e. To use appropriate words in the comic.
f. To add more explanations in diagram.
g. To add ending by adding 1 more panel.
h. To notify punctuations used: period, comma and italic.
i. To add pattern in thermochemistry.
j. To avoid exception words.

Moreover, there were found several obstacles in conducting this research as follows:

1. Cost

Releasing this comic book might cost a lot of money (pricey).

2. Researcher

The researcher is not fully-proficient in art designing, especially to skilfully design the displays of the comic book.

3. Media Experts

Not all lecturers or teachers have abilities in mastering learning media developments.

\section{Assessing}

In this stage, the comic was assessed by 3 (three) chemistry teachers and 30 (thirty) students from several selected school (SMK Muhammadiyah 2, SMA Internasional Budi Mulia Dua, and MA Wahid Hasyim). Precisely, the chemistry comic book developmental process was guided by supervisors, peerreviewers and media experts. The instrument used to evaluate the quality of this chemistry comic book is a set of quality which has some aspects and criteria. In details, the evaluation includes 9 (nine) aspects with 38 (thirty-eight) criteria. Meanwhile, for students' evaluation, it included 5 (five) aspects and 27 (twenty-seven) criteria. The evaluation result was presented in qualitative data, then the result was tabulated and analyzed by the ideal evaluation criteria and category in order to guide to measurement and assessment of the chemistry comic book quality which can be seen in table 1 and 2.

Table 1. Quality of Chemistry Comic Book Based on Teachers' Assessment

\begin{tabular}{|c|c|l|c|c|c|c|}
\hline No & Aspects & \multicolumn{1}{|c|}{ Criteria } & $\begin{array}{c}\text { Mean } \\
\text { Score }\end{array}$ & $\begin{array}{c}\text { Ideal Mean } \\
\text { Score }\end{array}$ & $\begin{array}{c}\text { Ideal } \\
\text { Percentage }\end{array}$ & Quality \\
\hline 1 & $\mathrm{~A}$ & $1,2,3$ & 12.33 & 15 & $82.20 \%$ & $\mathrm{E}$ \\
\hline 2 & $\mathrm{~B}$ & $4,5,6$ & 12.67 & 15 & $84.47 \%$ & $\mathrm{E}$ \\
\hline 3 & $\mathrm{C}$ & 7,8 & 7.67 & 10 & $76.70 \%$ & $\mathrm{G}$ \\
\hline 4 & $\mathrm{D}$ & $9,10,11$ & 11.67 & 15 & $77.80 \%$ & $\mathrm{G}$ \\
\hline 5 & $\mathrm{E}$ & $12,13,14,15,16$ & 19.33 & 25 & $77.32 \%$ & $\mathrm{G}$ \\
\hline 6 & $\mathrm{~F}$ & $17,18,19,20,21,22,23,24,25$ & 33 & 45 & $73.33 \%$ & $\mathrm{G}$ \\
\hline 7 & $\mathrm{G}$ & $26,27,28,29,30$ & 20 & 25 & $80 \%$ & $\mathrm{E}$ \\
\hline 8 & $\mathrm{H}$ & $31,32,33$ & 11.33 & 15 & 75.53 & $\mathrm{G}$ \\
\hline 9 & $\mathrm{I}$ & $34,35,36,37,38$ & 18.33 & 25 & $73.32 \%$ & $\mathrm{G}$ \\
\hline
\end{tabular}


Tarbiyah: Jurnal Ilmiah Kependidikan

Vol. 10 No. 1 January - June $2021(57-63)$

DOI: http://dx.doi.org/10.18592/tarbiyah.v10i1.3869

Table 2. Quality of Chemistry Comic Book Based on Students' Assessment

\begin{tabular}{|c|c|l|c|c|c|c|}
\hline No & Aspects & \multicolumn{1}{|c|}{ Criteria } & $\begin{array}{c}\text { Mean } \\
\text { Score }\end{array}$ & $\begin{array}{c}\text { Ideal Mean } \\
\text { Score }\end{array}$ & $\begin{array}{c}\text { Ideal } \\
\text { Percentage }\end{array}$ & Quality \\
\hline 5 & $\mathrm{E}$ & $12,13,14,15,16$ & 20.17 & 25 & $80.68 \%$ & $\mathrm{E}$ \\
\hline 6 & $\mathrm{~F}$ & $17,18,19,20,21,22,23,24,25$ & 35.83 & 45 & $79.62 \%$ & $\mathrm{G}$ \\
\hline 7 & $\mathrm{G}$ & $26,27,28,29,30$ & 19.67 & 25 & $78.68 \%$ & $\mathrm{G}$ \\
\hline 8 & $\mathrm{H}$ & $31,32,33$ & 12.33 & 15 & $82.20 \%$ & $\mathrm{E}$ \\
\hline 9 & $\mathrm{I}$ & $34,35,36,37,38$ & 18.33 & 25 & $73.32 \%$ & $\mathrm{G}$ \\
\hline
\end{tabular}

Whereas:

$\begin{array}{ll}\text { A } & =\text { Writing approach } \\ \text { B } & =\text { Truth of chemistry concept } \\ \text { C } & =\text { Depth of concept } \\ \text { D } & =\text { Breadth of concept } \\ \text { E } & =\text { Feasibility } \\ \text { F } & =\text { Linguistic } \\ \text { G } & =\text { Anatomy of comic } \\ \text { H } & =\text { Quality of images } \\ \text { I } & =\text { Comprehensive appearance } \\ \text { E } & =\text { Very good } \\ \text { G } & =\text { Good }\end{array}$

These data indicated that the quality of this chemistry-based comic is good and can be used as an alternative media in learning chemistry. According to Devi Afriyuni Yonanda et al (2019), comic could foster students' critical thinking ability which supported by another study finding that cartoon could give positive effects in student learning. Then, Green \& Myers (2014) also reported that embedding cartoon in curriculum design will increase students' interests in learning. This is in line with the study conducted by Fitri Dwi Arini (2017) that the use of comic as a learning aid could improve the learning interest of student.

Likewise, in this research, it was found that by using comic as a learning resource, it gave positive effects and reactions in student motivation and it could be used as a tool in effective learning (Wahyu Nuning \& Haryanto, 2016).

To start with, the first result of this research falls on the product of selflearning resource in the form of chemistry comic book for SMA (Senior High School) / MA (Islamic Senior High School) students in Thermochemistry subdiscussion. This chemistry comic book was written in Indonesian. Thus, all the obtained-data sourced from peers, media experts and assessors were translated to English in the report. This comic book included five sub- materials of thermochemistry, i.e. heat, enthalpy and enthalpy change, calculating enthalpy changes, calorimeter, and fuel. So that, to get constructive input for the research, reviews from supervisors, peers, and media experts have been managed and channeled in the comic development and innovation.

Then, the second result falls on the quality of chemistry comic book that has been developed based on the assessments of SMA/MA chemistry teachers and students in Yogyakarta. According to teachers' assessments, the chemistry comic book was considered to possess a good quality, reaching to the score of 146.33 from the maximum point of 190 and ideal percentage of $77.02 \%$. Similarly, based on students' assessment, it was also categorized as a good quality comic book within the result score of 106.33 from the maximum point of 135 and ideal percentage of $78.76 \%$.

\section{CONCLUSION}

The conclusions that can be driven from the research are as follows:

1. The researcher successfully compiled a chemistry comic book in thermochemistry chapter as a selflearning media for SMA/MA students of semester 1 at grade 11 . 
2. The chemistry comic book is wellqualified based on teachers'and students' assessment.

To sum up, the results of this study are used as input for teachers and prospective teachers as this chemistry comic book can be used and improved in learning process that involves both students and teachers' participations and assessments. All in all, in order to reach the optimum aim of learning and teaching process, teachers should be more creative and innovative in teaching, as well as students should be more active in learning to fully immerse on the learning experiences.

\section{REFERENCES}

Ahmad, Fadillah. (2018). Pengembangan Media Belajar Komik terhadap Motivasi Belajar Siswa. Jurnal Teori dan Aplikasi Matematika, 2(1), 36-42.

Ambaryani. (2017). Pengembangan Media Komik untuk Efektifitas dan Meningkatkan Hasil Belajar Kognitif Materi Perubahan Lingkungan Fisik. Jurnal Pendidikan Surya Edukasi (JSPE), 3(1), 19-28.

Azhar, Arsyad. (2008). Media Pembelajaran. Jakarta: Grafindo.

Devi Afriyuni Yonanda, Yuyu Yuliati, and Dudu Suhandi Saputra. (2019). Development of Problem-Based Comic Book as Learning Media for Improving Primary School Students' Critical Thinking Ability.
Mimbar Sekolah Dasar, 69(3), 341-48.

Efi Ika Febriandari, Bambang Yulianto, and Wahyu Sukartiningsih. (2016). Pengembangan Media Komik dalam Pembelajaran Model Round Table. Jurnal Kajian Pendidikan dan Hasil Penelitian, 2(3), 297-303.

Fitri Dwi Arini. (2017). The Use of Comic as A Learning Aid to Improve Learning Interest of Slow Learner Student. European Journal of Special Education, 2(1), 71-78.

Nuning Budiarti and Haryanto. (2016). Pengembangan Media Komik untuk Meningkatkan Motivasi Belajar dan Keterampilan Membaca Pemahaman Siswa Kelas IV. Jurnal Prima Edukasia, 4(2), 233-42.

Raymond Chang. (2005). Chemistry.. New York: McGraw-Hill Companies.

Saiful Efendi. (2016). Pembuatan Komik Super Jamu. Jurnal Pendidikan Seni Rupa, 4(3), 365-73.

Shannon Casey. (2006). The Place for Comics in Science Education. USA: Greenwood Publishing Group.

Teni Nurrita. (2018). Pengembangan Media Pembelajaran untuk Meningkatkan Hasil Belajar Siswa. Jurnal Ilmu Tarbiyah, 3(1), 171-87.

Utami Sulistya and A.K. Projosantoso. (2019). The Development of The Character-Based Science Comics Learning Medoia to Improve Self Reliance Learning the Students of SMP. Journal of Science Education Research, 3(1), 52-62. 